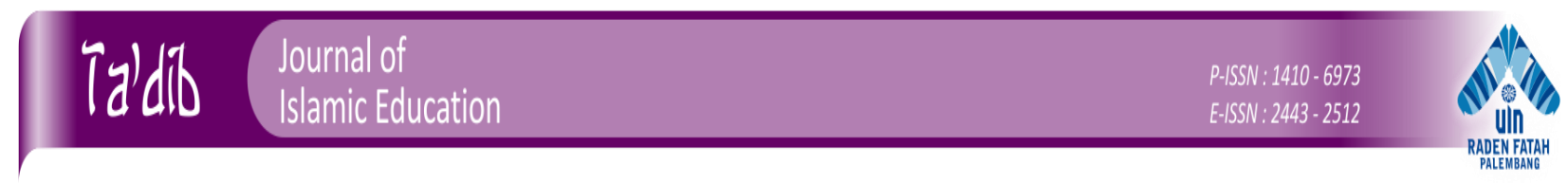

\title{
The Relationship of Self Efficacy towards Improving Quality of Santri Organization in Daar El-Qolam
}

\author{
Taufik Abdillah Syukur \\ taufik.a@uinjkt.ac.id \\ State Islamic University of Syarif Hidayatullah Jakarta Indonesia
}

\author{
Aisha Tara Athira \\ abdillah2803@gmail.com \\ Daar El-Qolam Islamic Boarding School
}

\begin{abstract}
In this modern era, for its rapid grown, Pesantren has played an important role in the development of Indonesian education. Daar El-Qolam is an institution based on a modern pesantren system that has a principle to create a good future generation. By using their principle and implement it to all santri, it is expected that it can increase their lead. In actualizing their purpose, pesantren has created a good system both academic and non-academic. To improve their abilities, santri needs a place and chance to increase and to improve their abilities. One of the pesantren programs is to obligate all santri from class 5 to be a manager in daily activities in pesantren. The purpose of this study case is to know the relationship of self-efficacy in improving the quality of santri organization in Daar El-Qolam. The method used in research was quantitative research design that used correlational method method to know the relationship of Self-Efficacy in improving Quality of Santri Organization in Daar El-Qolam. Based on the result of research that has been done regarding the relationship of Self efficacy towards improving santri organization in Daar ElQolam, there was the significant relationship of Self efficacy in improving quality of santri organization in Daar El-Qolam.
\end{abstract}

Keywords: Quality, Santri organization, Self-efficacy

\section{Introduction}

In this modern era, for its rapid grown, Pesantren has played an important role in the development of Indonesian education. Daar El-Qolam is an Institution based on a modern pesantren system that has a principle to create a good future generation. Their principle that have implemented to all santri is expected to increase their leadership. In actualizing their purpose, pesantren has created a good system both academic and non-academic. To improve their abilities, santri needs a place and chance to increase and improve their abilities. One of the pesantren programs is to obligate all santri from class 5 to be a manager in daily activities in pesantren. Being a manager is a big trust to uphold the discipline and to achieve their work program. Santri organization or recently is called ISMI (Ikatan santri madrasatul muallimin al-islamiyah). This organization consists of some divisions. In every division, it requires 2 until 12 people to maximize their tasks and work programs. A lot of problems and conflicts in perform their tasks or work programs often occured and it came from themselves such, as a lack of their 
willingness or lack of their sense of belonging to achieve what they want. Besides, they are not encouraged through their improvement or they don't get any achievement to make them more couraged in increasing their motivation to do all of the tasks.

Self-efficacy here is a theory that is also known as a social cognitive theory or social learning theory (Bandura) or the theory that refers to an individual belief that he or she is capable of performing the task. The main concept in social cognitive theory is that an individual's actions and reactions, including social behaviors and cognitive processes, in almost every situation are influenced by the actions that an individual has observed in others (Munandar, 2002). Because self-efficacy is developed from external experiences and self-perception and is influential in determining the outcome of many events, it is important in the self-efficacy theory. Besides, the relationship between self-efficacy and santri organization is used to compare who has a high selfefficacy and doesn't have a high self-efficacy. That is why the author decided to research these things in this scientific paper entitled The Relationship of Self Efficacy towards Improving Quality of Santri Organization in Daar El-Qolam.

Due to the limitations of time and opportunity in the research, in order to make the scientific research directed well and effectively, the writer restricts and discusses only on the variable of X: The relationship of Self Efficacy Y: Improving quality of santri organization in Daar El-Qolam. The purpose of this study is to know the relationship of self-efficacy towards improving the quality of santri organization in Daar El-Qolam.

\section{Literature Review}

\section{The concept of self-efficacy}

Self-efficacy is an individual's belief in their innate ability to achieve goals. Bandura (1997) states that belief in innate abilities means valuing one's particular set of conative strengths. It also involves determination and perseverance to overcome obstacles that would interfere with utilizing those innate abilities to achieve goals. Bandura also defines it as a students' judgment of how well one can execute courses of action required to deal with prospective situations. Expectations of self-efficacy determine whether an individual will be able to exhibit coping behavior and how long an effort will be sustained in the face of obstacles. Individuals who have high self-efficacy will exert sufficient effort that, if well-executed, leads to successful outcomes, whereas those with low self-efficacy are likely to cease effort early and fail. Psychologists have studied self-efficacy from several perspectives, noting various paths in the development of self-efficacy; the dynamics of self-efficacy, and lack of, in many different settings interactions between self-efficacy and self-concept and habits of attribution that contribute to, or detract from, self-efficacy.

Self-efficacy affects every area of human endeavor. By determining the beliefs a students holds regarding their power to affect situations, it strongly influences both the power a students has to face challenges competently and the choices a students is most likely to make. These effects are particularly apparent, and compelling, with regard to behaviors affecting health. Self- efficacy is the belief we have in our abilities, specifically our ability to meet the challenges ahead of us and complete a task successfully (Ackerman, 2019). General self-efficacy refers to our overall belief in our ability to succeed, but there are many more specific forms of self-efficacy as 
well (e.g., academic, parenting, sports). Although self-efficacy is related to our sense of self- worth or value as a human being, there is at least one important distinction (Ackerman, 2019).

Self-efficacy vs. Self-esteem, self-esteem is conceptualized as a sort of general or overall feeling of one's worth or value (Neill, 2005). While self-esteem is focused more on "being" (e.g., feeling that you are perfectly acceptable as you are), self-efficacy is more focused on "doing" (e.g., feeling that you are up to a challenge). High self-worth can improve one's sense of self- efficacy, as high self-efficacy can contribute to one's sense of overall value or worth, but the two stand as separate constructs.

Self-efficacy and Self-regulation, since self-efficacy is related to the concept of self-control and the ability to modulate your behavior to reach your goals, it can sometimes be confused with self-regulation. They are related, but still separate concepts. Self-regulation refers to an individual's "self-generated thoughts, feelings, and actions that are systematically designed to affect one's learning," while self-efficacy is a concept more closely related to an individual's perceived abilities. In other words, self-regulation is more of a strategy for achieving one's goals, especially about learning, while self-efficacy is the belief that he or she can succeed. The two can be simultaneously developed — particularly through modeling — but they remain distinct constructs (Zimmerman \& Schunk, 2008).

Self-efficacy and motivation, similarly, although self-efficacy and motivation are deeply entwined, they are also two separate constructs (Chuang, Shiu \& Cheng, 2010). Self-efficacy is based on an individual's belief in their capacity to achieve, while motivation is based on the individual's desire to achieve. Those with high self-efficacy likely have high motivation and vice versa, but it is not a foregone conclusion. Still, it is true that when individual gains or maintains self-efficacy through the experience of success - however small-they generally get a boost in motivation to continue learning and making progress. The relationship can also work in the other direction to create a sort of success cycle; when an individual is highly motivated to learn and succeed, they are more likely to achieve their goals, giving them an experience that contributes to their overall self-efficacy.

Self-efficacy and resilience, while experiences of success certainly make up a large portion of self-efficacy development, there is also room for failure. Those with a high level of self-efficacy are not only more likely to succeed, but they are also more likely to bounce back and recover from failure. This is the ability at the heart of resilience, and it is greatly impacted by self-efficacy.

Self-efficacy and confidence, finally, self-efficacy is also positively related to confidence, but they are not the same thing; in the words of Albert Bandura. Just as with self-esteem and motivation, self-efficacy and confidence can work in a positive cycle the more confident a students is in his abilities, the more likely he is to succeed, which provides him with experiences to develop his self-efficacy. This high self-efficacy, in turn, gives him more confidence in himself, and round it goes (Zimmerman \& Schunk, 2008).

\section{The way to Increase Self-Efficacy}

Mastery experiences, the first and foremost source of self-efficacy is through mastery experiences. However, nothing is more powerful than having a direct experience of mastery to increase self-efficacy. Having a success, for example in mastering a task or controlling an environment, will build self- belief in that area whereas failure will undermine that efficacy 
belief. To have a resilient sense of self-efficacy requires experience in overcoming obstacles through effort and perseverance.

Vicarious experience, the second source of self-efficacy comes from our observation of people around us, especially people we consider as role models. Seeing people similar to ourselves succeed by their sustained effort raises our beliefs that we too possess the capabilities to master the activities needed for success in that area.

Verbal persuasion, influential people in our lives such as parents, teachers, managers or coaches can strengthen our beliefs that we have what it takes to succeed. Being persuaded that we possess the capabilities to master certain activities means that we are more likely to put in the effort and sustain it when problems arise.

Emotional \& physiological states, the state you're in will influence how you judge your self-efficacy. Depression, for example, can dampen confidence in our capabilities. Stress reactions or tension are interpreted as signs of vulnerability to poor performance whereas positive emotions can boost our confidence in our skills. Almost of managers being depression when they found one member doesn't obey the rules.

Imaginal experiences, psychologist James Maddux has suggested a fifth route to selfefficacy through "imaginal experiences", the art of visualizing yourself behaving effectively or successfully in a given situation (Haslin, 2019).

\section{How self-efficacy affects human function}

Choices regarding behavior, people generally avoid tasks where self-efficacy is low but undertake tasks where self-efficacy is high. When self-efficacy is significantly beyond actual ability, it leads to an overestimation of the ability to complete tasks. On the other hand, when selfefficacy is significantly lower than actual ability, it discourages growth and skill development. Research shows that the optimum level of self-efficacy is slightly above ability in this situation, people are most encouraged to tackle challenging tasks and gain experience Self- efficacy is made of dimensions like magnitude, strength, and generality to explain how one believes they will perform on a specific task.

Motivation, high self-efficacy can affect motivation in both positive and negative ways. In general, people with high self-efficacy are more likely to make efforts to complete a task, and to persist longer in those efforts, than those with low self-efficacy. The stronger the self-efficacy or mastery expectations, the more active the efforts. However, those with low self-efficacy sometimes experience incentives to learn more about an unfamiliar subject, where someone with a high selfefficacy may not prepare as well for a task. A negative effect of low self-efficacy is that it can lead to a state of learned helplessness. Learned helplessness was studied by Martin Seligman in an experiment in which shocks were applied to animals. Through the experiment, it was discovered that the animals placed in a cage where they could escape shocks by moving to a different part of the cage did not attempt to move because they had formerly been placed in a cage in which escape from the shocks was not possible. Low self-efficacy can lead to this state in which it is believed that no amount of effort will make a difference in the success of the task at hand. For example, managers in accomplish their tasks need external motivation both teacher friends so, they will have a good willingness to perform their duties.

Work performance, self-efficacy theory has been embraced by management scholars and practitioners because of its applicability in the workplace. Overall, self-efficacy is positively and 
strongly related to work-related performance. This relationship, though, depends on task complexity. (Goulão, 2014). For more complex tasks, the relationships between self-efficacy and work performance are weaker than for easier work-related tasks. This research implies that managers should provide accurate descriptions of tasks and provide clear and concise instructions and they should provide the necessary supporting elements for employees to be successful. Changed the focus on whether self-efficacy is related to performance, and focused the field on more specific questions, such as nature and underlying mechanisms responsible for producing the positive effect of self-efficacy on performance.

Thought patterns and responses, self-efficacy has several effects on thought patterns and responses:

- Low self-efficacy can lead people to believe tasks to be harder than they are. This often results in poor task planning, as well as increased stress.

- $\quad$ People become erratic and unpredictable when engaging in a task in which they have low self-efficacy.

- $\quad$ People with high self-efficacy tend to take a wider view of a task to determine the best plan.

- Obstacles often stimulate people with high self-efficacy to greater efforts, where someone with low self-efficacy will tend toward discouragement and giving up.

- $\quad$ A students with high self-efficacy will attribute failure to external factors, where a students with low self-efficacy will blame low ability. For example, someone with high self- efficacy in regards to mathematics may attribute a poor test grade to a harder-than-usual test, illness, lack of effort, or insufficient preparation. A students with a low self-efficacy will attribute the result to poor mathematical ability. A manager who has a low self-efficacy, they will feel unconfident to perform their task. They will put off their job and they will not do their tasks completely.

Relationship to loss of control, Bandura (1997) showed that differences in self-efficacy correlate to fundamentally different world views. People with high self-efficacy generally believe that they are in control of their own lives, that their actions and decisions shape their lives, while people with low self-efficacy may see their lives as outside their control. For example, a manager with high self-efficacy who does poorly on doing their task will likely at tribute the failure to the fact that they did not effort enough. However, a manager with low self- efficacy who does poorly on doing their task is likely to believe the cause of that failure was due to the task being too difficult or challenging or they will blame their supervisors about how their critic (Haslin, 2019).

\section{Santri organization (ISMI)}

The organization of ISMI or Ikatan Santri Mualimin Al Islamiyah is an Organization of santri boarding schools in fulfilling leadership education. This stewardship program is a chance for 5 th-grade students in developing their leadership abilities and talents in applying and guiding members in the discipline. In the running of this program, santri did not escape from their supervisor's guidance or their teachers in carrying out their duties. In organizing, there must be targets and work programs that must be implemented and carried out both in the daily, weekly, monthly and annual programs. In creating an effective organizational system and implementing a 
joint work program, an organization must have a member section to carry out all its programs. A program will depend on how their effort in performing their tasks.

ISMI has a representative in every part. The Chairstudents of ISMI oversees all parts as a whole from extracurricular disciplines and activities. Examples of daily parts such, language Activities, worship, scout, discipline, health, etc. Whereas in the extracurricular section or nonacademic enhancement of santri such as the arts section, academic creation of santri (KAS) in charge of parts such as robotic parts, Jamiyatul Huffazil Qur'an, Jamiyatul Qurro, Agriculture, Special public speaking club (EL-MARKAZI), Daar El-Qolam Debating Club (DDC), Water Rockets and others. Each field has responsibilities and work programs that must be carried out. In carrying out activities, there is always an evaluation in improving the quality of work of each individual or the whole organization that doesn't escape mistakes. The vision and mission of ISMI are to make uswatun hasanah leaders in every member or manager's selves. So, ISMI can be a part of education outside the class. According to their purpose, every member of class 5 has to be a part of this organization in order to have good experience and to prepare their life in the future.

\section{Methodology}

This research employed a quantitative research method. The design of the reseacrch was correlational design. This research was conducted at Daar El-Qolam Islamic Boarding School which is located in Pasir Gintung KM.36. The population in this study was 171 fifth grade students of Daar El-Qolam. We took 30 santri from the fifth grade of Daar El-Qolam to be the informants who answered the questionnaire.

To receive the needed source of data analysis and to have the exact and valid data, the author gave a research questionnaire to the participants of this research, the fifth graders of Daar El-Qolam. The main data source from this study was obtained from the results of a questionnaire with 30 out of 171 grade 5 students of Daar El-Qolam. The source of supporting data was obtained from the website and books written by certain writers in which the validation and accuracy of the theory can be trusted.

We used a questionnaire which is part of the data collection technique by giving the questionnaire to the related respondents (sample) to search whether there was the relationship of self-efficacy towards improving quality of organization of santri of class 5 in Daar El-Qolam or not.

The instrument was compiled in the form of a questionnaire that was developed using a Likert scale of three alternatives choices, namely: agree, doubt, and disagree. The answer score of three alternatives slopes upwards from the highest score to the smallest score. By the score as the following: Very agree: 5, Agree: 4, Doubt: 3, Disagree: 2, Very disagree: 1. Items in the qustionnaire were divided into two different variables. Item 1 to item 6 were made to gain santri's responses toward improving quality of santri organization (variable y). Meanwhile item 7 to item 12 were made to gain santri's responses toward santri's self efficacy (variable $\mathrm{x}$ ).

Because the sample in this research was taken randomly from the obvious population, we used quantitative analysis techniques in the form of inferential statistics by using product moment correlation so that the process carried out became effective and the results were perfectly achieved. The results of research data processing in the form of discrete data were then be used to conclude research objectives. 


\section{Findings}

To know the information concerning the relationship of self-efficacy towards improving the quality of santri organization in Daar El-Qolam, thus in this section, the description of data found on each response was explained. Data concerning the respondents' responses about analysis of self-efficacy towards improving santri organization in Daar El-Qolam through the answers given on the questionnaire. The questionnaires were spread out randomly to 30 (thirty) fifth grade students of Daar El-Qolam. To analyze the data, the answers of questionnaire were quantified and compiled based on the variable of research (variable $\mathrm{x}$ refers to self efficacy of the santri and the quality improvement of santri organization and variable y).

The researched indicator is the relationship of self-efficacy towards improving santri organization in Daar El-Qolam. From the indicators, it is developed to be 6 statements that must be answered by the respondents. In every question, its item is already provided alternative question gradually. To ease the scoring in every item, it employed the scale of Likert scale, so that in each item provided 5 alternative questions namely: Strongly agree (5), Agree (4), Doubt (3), Disagree (2), Strongly disagree (1).

After that, the numerical data obtained from the questionnaire were distributed and tabulated into a table. After that, the data were analyzed by using the correlation product moment to see the degree of correlation. The result of the questionnaire which spread by writer, as follow:

Table 1. The results of the questionnaire

\begin{tabular}{|c|c|c|c|c|c|c|}
\hline No & STATEMENT & SA & $\mathbf{A}$ & DO & D & D \\
\hline & \multicolumn{6}{|l|}{ Questionnaire of Variable $Y$} \\
\hline 1 & $\begin{array}{l}\text { Self-efficacy has an important role } \\
\text { in increase quality of ISMI manager }\end{array}$ & 21 & 8 & 1 & - & - \\
\hline 2 & $\begin{array}{l}\text { The motivation from other people } \\
\text { can encourage the manager to } \\
\text { improve their qualities }\end{array}$ & 15 & 15 & - & - & - \\
\hline 3 & $\begin{array}{l}\text { My supervisor doesn't give me a } \\
\text { difficult task }\end{array}$ & 7 & 7 & 8 & 1 & - \\
\hline 4 & $\begin{array}{l}\text { I never ask an evaluation to the } \\
\text { supervisor }\end{array}$ & 5 & 15 & 8 & 1 & - \\
\hline 5 & $\begin{array}{l}\text { The managing quality could be } \\
\text { increased without any self-efficacy }\end{array}$ & 2 & 3 & 4 & 12 & 8 \\
\hline \multirow[t]{2}{*}{6} & $\begin{array}{l}\text { Self-efficacy cannot encourage me } \\
\text { and the other manager to do our task }\end{array}$ & 1 & 3 & 3 & 16 & 7 \\
\hline & \multicolumn{6}{|l|}{ Questionnaire of Variable X } \\
\hline 7 & $\begin{array}{l}\text { As a manager I don't get any } \\
\text { change from myself }\end{array}$ & 2 & 2 & 1 & 12 & 3 \\
\hline 8 & $\begin{array}{l}\text { I often feel frightened in doing my } \\
\text { tasks }\end{array}$ & 9 & 20 & 1 & - & - \\
\hline
\end{tabular}




\begin{tabular}{|c|c|c|c|c|c|c|}
\hline $\left.\int y\right) d x$ & $\begin{array}{l}\text { Journal of } \\
\text { Islamic Education }\end{array}$ & & & & $\begin{array}{l}\text { P.ISSN : } 1410-6973 \\
\text { E.ISSN : } 2443-2512\end{array}$ & \\
\hline 9 & $\begin{array}{l}\text { I always thought that I able to } \\
\text { complete my tasks on time }\end{array}$ & 8 & 5 & 3 & - & - \\
\hline 10 & $\begin{array}{l}\text { A difficult task could encourage me } \\
\text { to do my tasks immediately }\end{array}$ & 4 & 11 & 13 & 2 & - \\
\hline 11 & $\begin{array}{l}\text { I always get a negative advices from } \\
\text { my supervisors }\end{array}$ & 4 & 10 & 6 & 5 & 3 \\
\hline 12 & I often feel upset after being advised & 3 & 5 & 6 & 9 & 7 \\
\hline
\end{tabular}

After data decribed in the table above, every statement in the questionnaire was explained in the pie chart below:

\section{Self-efficacy has an important role in increasing quality of ISMI manager}

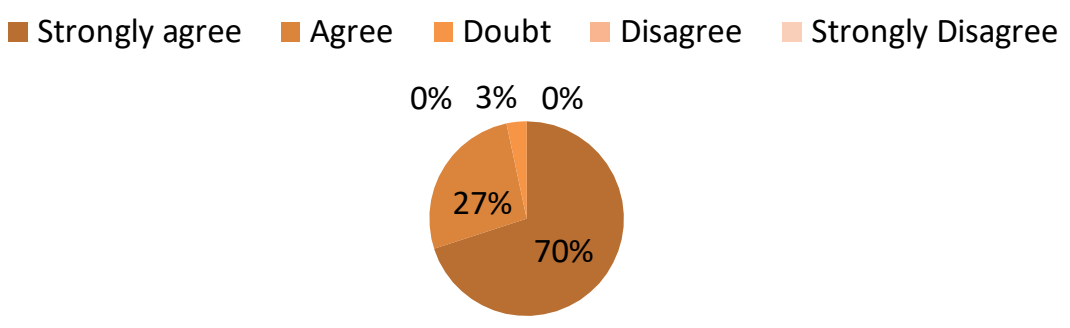

Figure 1. First statement

From data above, it can be concluded that from 30 respondents, there were 21 students or $70 \%$ who answered strongly agree, 8 students or $27 \%$ who answered agree, 1 students or $3 \%$ who answered doubt, and there was no answer or $0 \%$ who answered disagree or strongly disagree. Interpretation from that data that majority of student fifth grade strongly agreed that self-efficacy has an important role in increasing quality of ISMI manager.

The motivation from the other people can encourage the manager to improve their qualities

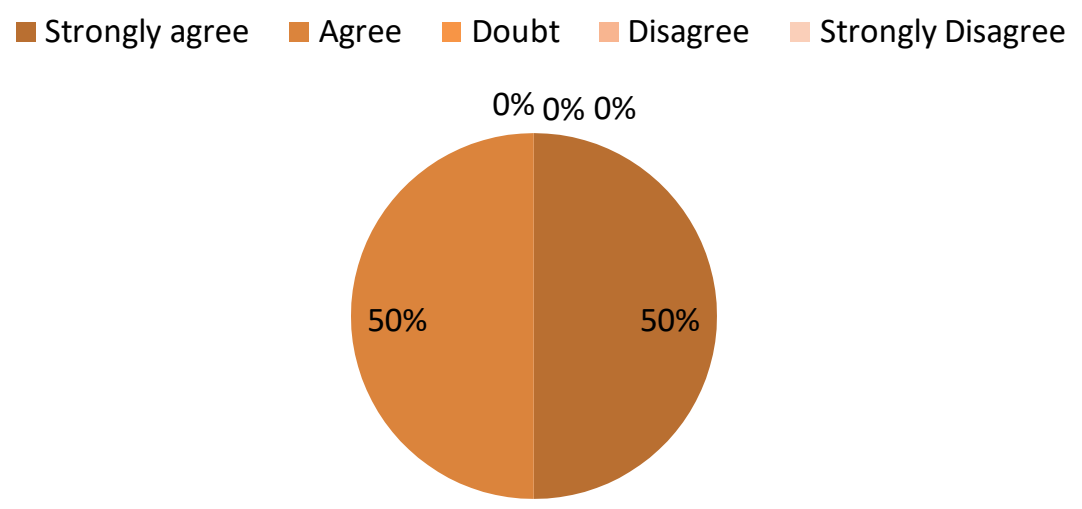

Figure 2. Second statement

Ta'dib: Journal of Islamic Education • Volume 24, Number 2, December 2019 Available online at http://jurnal.radenfatah.ac.id/index.php/tadib 
From data above, it can be concluded that from 30 respondents, there were 15 students or $50 \%$ who answered strongly agree, 15 students or 50\% who answered agree, and there were no answers or $0 \%$ who answered doubt, disagree and strongly disagree.

My supervisor (teacher) does not give me a difficult task

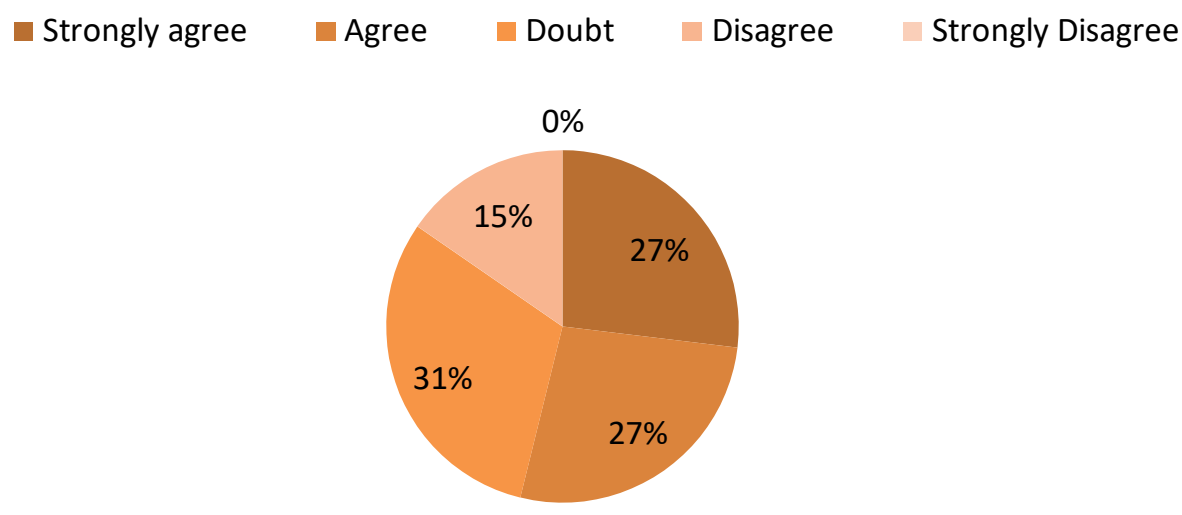

Figure 3. Third statement

From data above, it can be concluded that from 30 respondents, there were 7 students or $27 \%$ who answered strongly agree, 7 students or $27 \%$ who answered agree, 8 students or $31 \%$ who answered doubt, 4 students or $15 \%$ who answered doubt and there were no answers or $0 \%$ who answered strongly disagree.

I never ask for an evaluation from the supervisors.

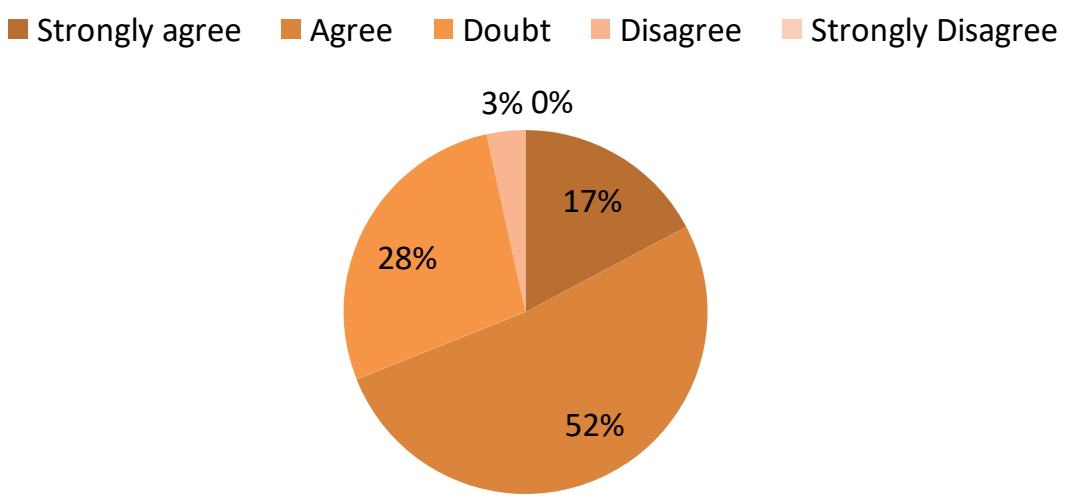

Figure 4. Fourth statement

From data above, it can be concluded that from 30 respondents, there were 5 students or $18 \%$ who answered strongly agree, 15 students or $53 \%$ who answered agree, 8 students or $28 \%$ 
who answered doubt, 1 students or $3 \%$ who answered doubt and there were no answers or $0 \%$ who answered strongly disagree.

The management quality can be increased without any self-efficacy

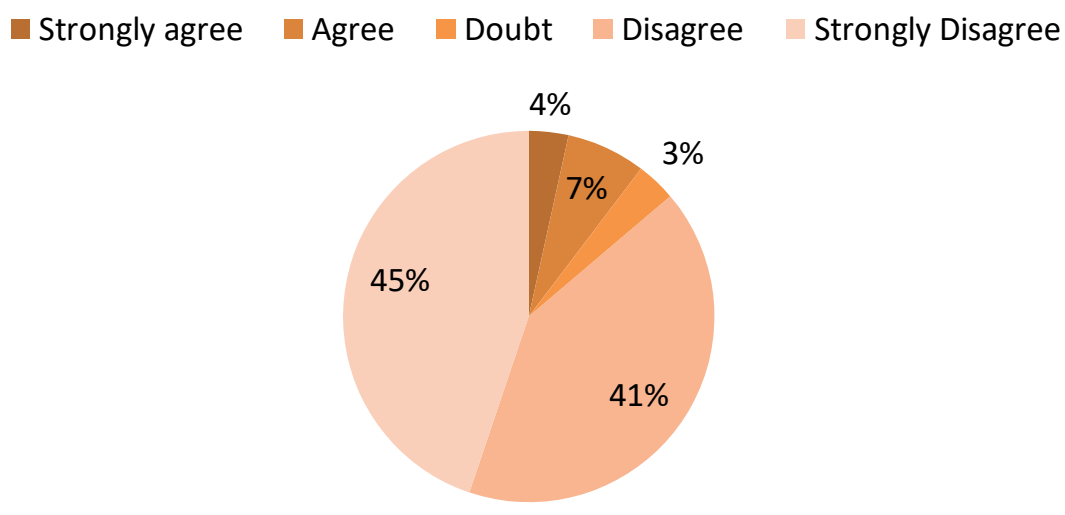

Figure 5. Fifth statement

From data above, it can be concluded that from 30 respondents, there were 1 students or $4 \%$ who answered strongly agree, 2 students or $7 \%$ who answered agree, 1 students or $3 \%$ who answered doubt, 12 students or $41 \%$ who answered doubt and 13 or $45 \%$ who answered strongly disagree.

Self-efficacy cannot encourage me and the other managers to do our tasks.

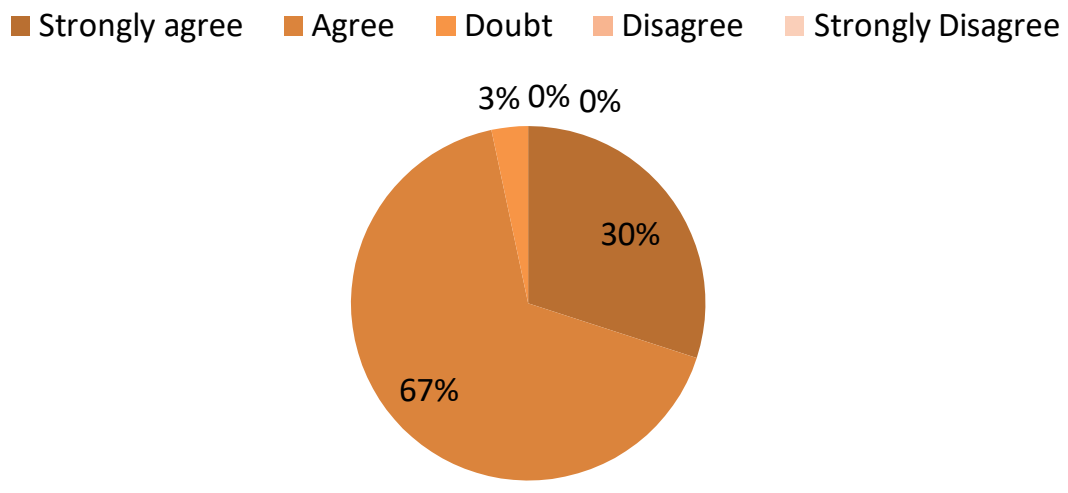

Figure 6. Sixth statement

From data above, it can be concluded that from 30 respondents, there were 9 students or $30 \%$ who answered strongly agree, 20 students or $67 \%$ who answered agree, 1 students or $3 \%$ who answered doubt, and there was no answer or $0 \%$ who answered disagree and strongly disagree. 


\section{I always think that I am able to complete my tasks on time}

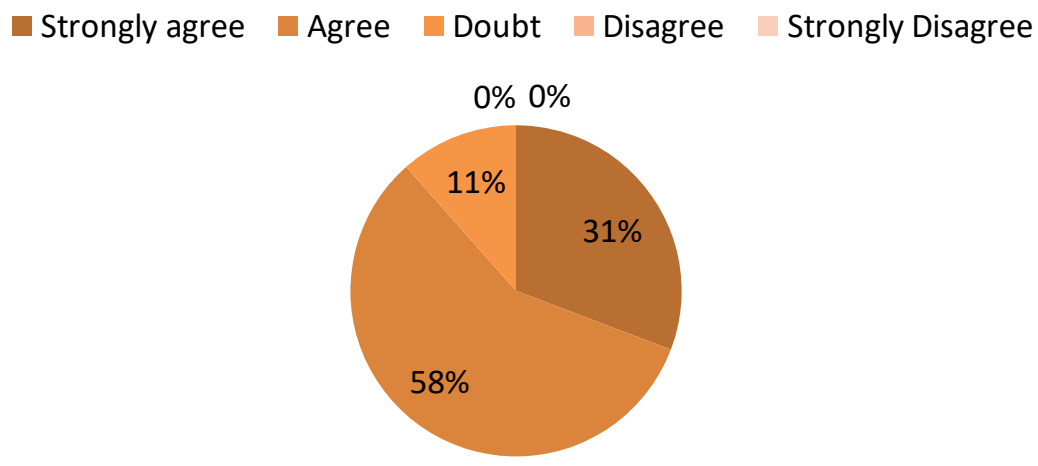

Figure 7. Seventh statement

From data above, it can be concluded that from 30 respondents, there were 8 students or $31 \%$ who answered strongly agree, 15 students or $58 \%$ who answered agree, 3 students or $11 \%$ who answered doubt, and there were no answers or $0 \%$ who answered disagree and strongly disagree.

\section{A difficult task can encourage me to do my tasks immediately}

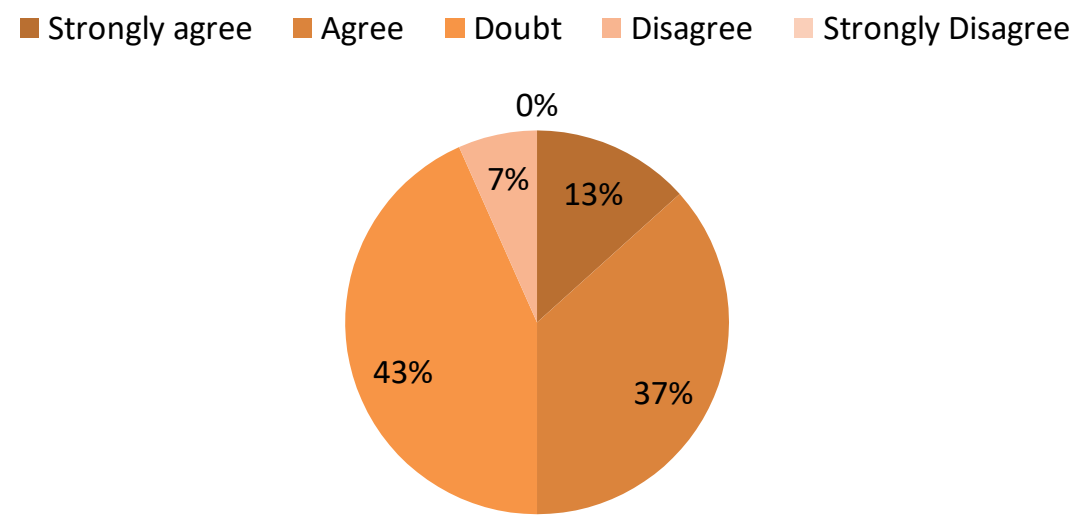

Figure 8. Eight statement

From data above, it can be concluded that from 30 respondents, there were 4 students or $13 \%$ who answered strongly agree, 11 students or $37 \%$ who answered agree, 13 students or $43 \%$ who answerd doubt, and 2 students or $7 \%$ who answerd disagree there were no answers or $0 \%$ who answered strongly disagree. 
The managing quality could be increased without any self-efficacy

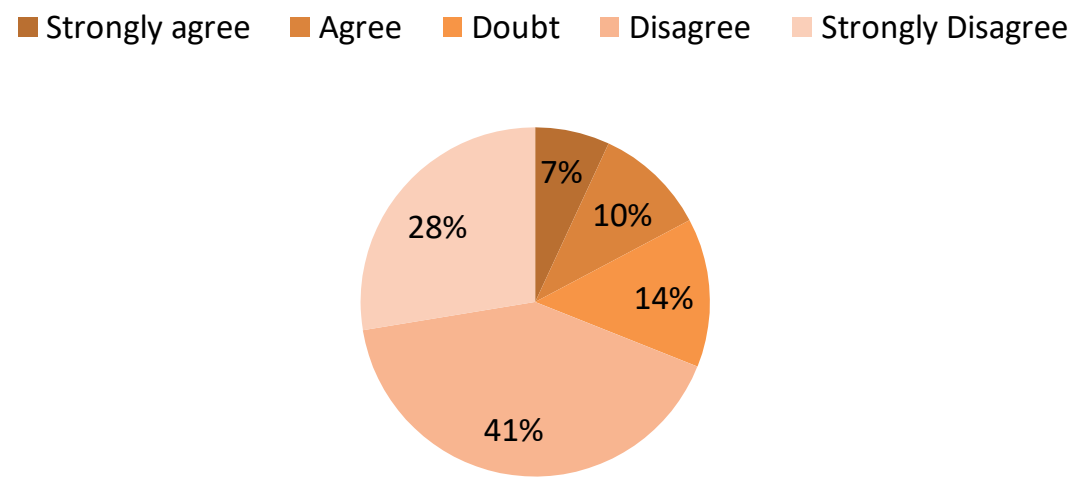

Figure 9. Ninth statement

From data above, it can be concluded that from 30 respondents, there were 2 students or $7 \%$ who answered strongly agree, 3 students or $10 \%$ who answered agree, 4 students or $14 \%$ who answered doubt, and 12 students or $41 \%$ who answered disagree and 8 students or $28 \%$ who answered strongly disagree.

Self-efficacy can encourage me and the other manager to do our task

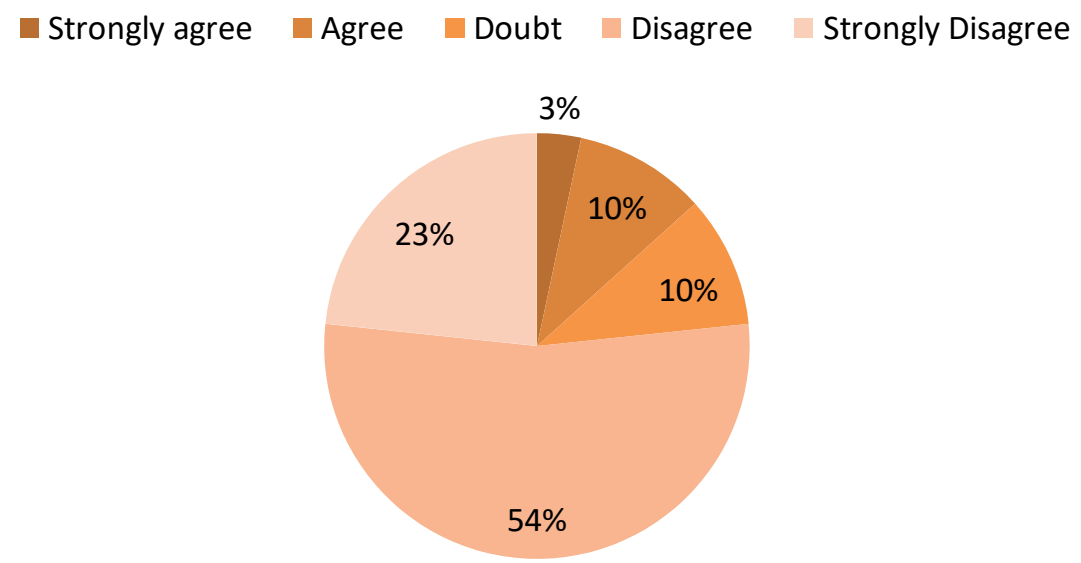

Figure 10. Tenth statement

From data above, it can be concluded that from 30 respondents, there were 1 students or $3 \%$ who answered strongly agree, 3 students or $10 \%$ who answered agree, 3 students or $10 \%$ who answered doubt, and 16 students or $54 \%$ who answered disagree and 7 students or $24 \%$ who answered strongly disagree. 


\section{I always get a negative advice from my supervisor}

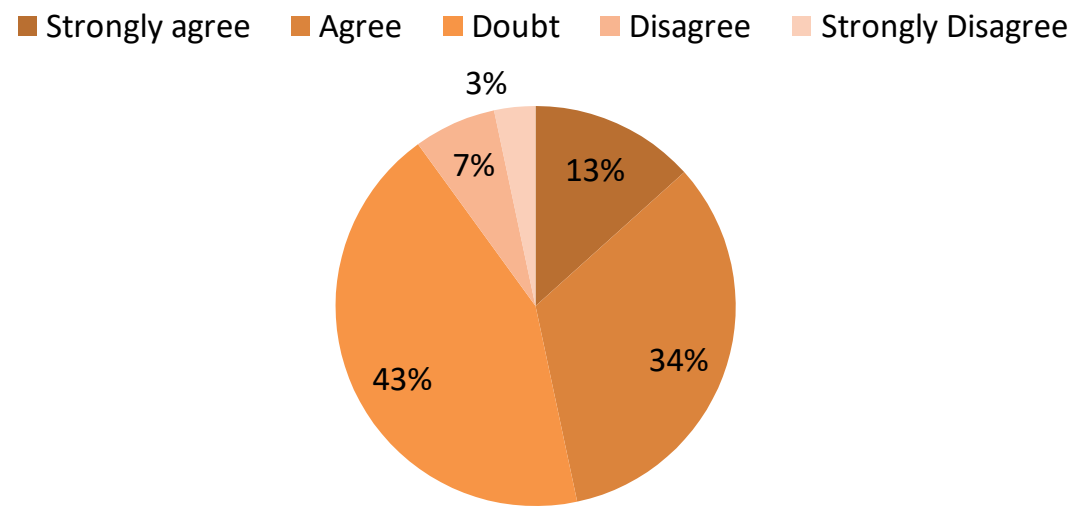

Figure 11. Eleventh statement

From data above, it can be concluded that from 30 respondents, there were 4 students or $13 \%$ who answered strongly agree, 10 students or $34 \%$ who answered agree, 13 students or $43 \%$ who answered doubt, and 2 students or $7 \%$ who answered disagree and 1 students or $3 \%$ who answered strongly disagree.

\section{I often feel upset after being advised}

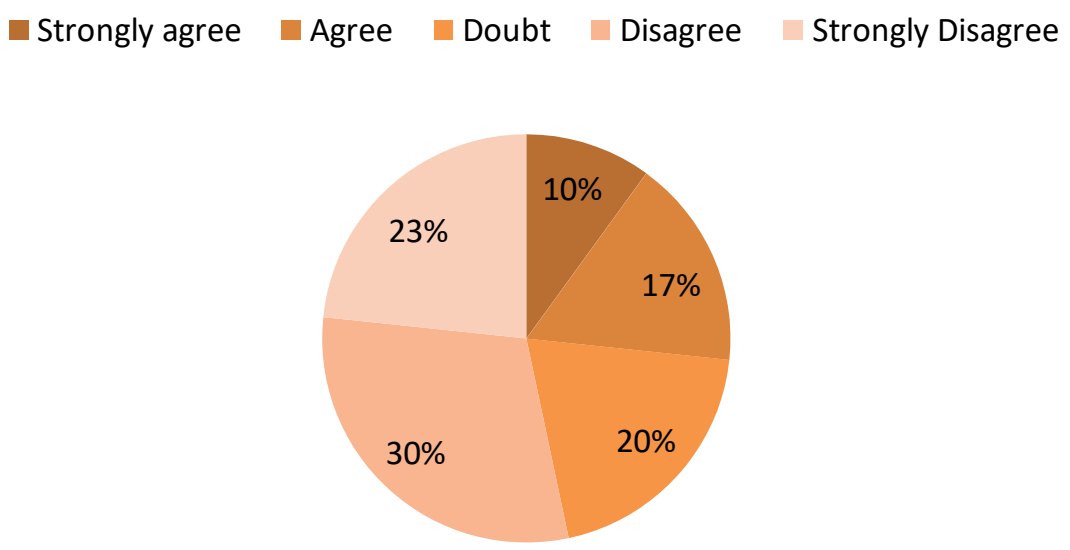

Figure 12. Twelft statement

From data above, it can be conclude that from 30 respondents, there were 3 students or $10 \%$ who answered strongly agree, 5 students or $17 \%$ who answered agree, 6 students or $20 \%$ who answered doubt, and 6 students or $30 \%$ who answered disagree and 7 students or $23 \%$ who answered strongly disagree.

The results of the data gained from the questinnaire then were analyzed by using Pearson Product Moment correlation with SPSS 21 to see whether there was correlation between variable $\mathrm{x}$ which refers to self efficacy of the santri and variable $\mathrm{y}$ which refers to the quality 
improvement of santri organization. The results of the calculation showed the estimated $\mathrm{p}$ value (Sig.) of 0,000 . Since the significant value is less than $\alpha=0.05$, it can be concluded that there was significant relationship between self-efficacy and quality improvement of santri organization. The correlation coefficient value of the two variables is 0.444 . It is in the range between $0,40-0.599$. It means that the relationship between the two variables is medium.

\section{Discussion}

Based on the result of research that has been done by us, it showed that there was the relationship of Self-efficacy towards quality improvement of santri organization. Albert Bandura (1997) states belief in innate abilities means valuing one's particular set of conative strengths. It also involves determination and perseverance to overcome obstacles that would interfere with utilizing those innate abilities to achieve goals. He also defines it as a judgment of how well one can execute courses of action required to deal with prospective situations. Expectations of selfefficacy determine whether an individual will be able to exhibit coping behavior and how long an effort will be sustained in the face of obstacles. Individuals who have high self-efficacy will exert sufficient effort that, if well-executed, leads to successful outcomes, whereas those with low selfefficacy are likely to cease effort early and fail.

Thus it can be seen from the responses of the quetionnaire that santri with high selfefficacy will be able to carry out tasks, activities or actions and continue to strive if they encounter obstacles in achieving their goals. Self-efficacy is needed towards improving the quality of santri organization. Therefore, all of the managers have to be aware of all their tasks by improving their self-efficacy. Besides, they are also expected to have a good sense of belonging towards improving the quality of santri organization in Daar El-Qolam.

\section{Conclusion}

Based on the result of research that has been done by the writer regarding the relationship of Self-efficacy towards improving santri organization in Daar El-Qolam, the writer states: "There was significant relationship of Self-efficacy existence towards improving quality of santri organization in Daar El-Qolam".

\section{References}

Ackerman, C. (2019). Positive Physchologist Program. Retrieved from https://positivepsychologyprogram.com/self-efficacy/.

Bandura, A. (1997). Self efficacy: The exercise of control. New York, NY: Freeman.

Chuang, C. F., Shiu, S. C., \& Cheng, C. J. (2010). The Relation of College Students' Process of Study and Creativity: The Mediating Effect of Creative Self-Efficacy. World Academy of Science, Enginering and Technology.

Goulão, M. d. (2014). The Relationship between Self-Efficacy and Academic Achievement in Adults' Learners. Athens Journal of Education. Retrieved from https:// Athens Journal of Education.com/

Haslin, P. (2019). Understanding and developing self efficacy. Research Gate .https://en.wikipedia.org/wiki/Self-efficacy. (n.d.). Retrieved july monday, 2019, from https://en.wikipedia.org/wiki/Self-efficacy. 
Munandar, S. C. U. (2002). Kreativitas dan keberbakatan. Jakarta, Indonesia: PT. Gramedia Pustaka Utama.

Neill, J. (2005). Definitions of various self constructs: Self esteem, self efficacy, self confidence and self concept. Accessed in http://wilderdom.com/self/.

Zimmerman, B.J., \& Schunk, D.H. (2008). , Motivation: An essential dimension of self regulated learning. In D.H. Schunk \& B.J. Zimmerman(Eds.), Motivation and self regulated learning: Theory, research and application (pp. 1-30). Mahwah, NJ, US: Lawrence Erlbaum Associates Publishers. 